\title{
Learning that Makes a Difference: Pedagogy and Practice for Learning Abroad
}

\section{ABSTRACT}

Society faces significant new challenges surrounding issues in human health; global security; environmental devastation; human rights violations; economic uncertainty; population explosion and regression; recognition of diversity, difference and special populations at home and abroad. In light of these challenges, there is a great opportunity, and a great need, for education that makes a difference in the way students think and interact with their world. This article has three objectives. The first is to present an overview of the literature on the global trend to internationalize the higher education curriculum. The second is to briefly highlight some of the key pedagogical concepts established in the work of pedagogical trailblazers John Dewey, Paulo Freire, and Jack Mezirow and synthesize them in relation to learning abroad. Finally, the article concludes with a discussion of how a synthesis of these pedagogical models, applied to the context of international learning experiences, has the potential to support transformative learning that makes a difference in how students think about and engage with complex global issues.

\section{KEYWORDS}

leadership, learning abroad, social impact, transformational pedagogy

Society faces significant new challenges surrounding issues such as human health; global security; environmental devastation; human rights violations; and economic uncertainty. There is a great opportunity, and a great need today, for education that makes a difference in how students think about and engage with complex global issues and others in their world. Students who participate in international learning programs can gain the advantage of first-hand experience with some of these concerns. However, without a robust and carefully considered pedagogical framework for reflecting on and interpreting their experiences abroad, students will be no better equipped to understand or engage with these complex problems. Furthermore, inadequate preparation may result in students developing unfair, misinformed or even oppressive interpretations of the social contexts in which they are learning. Educational institutions offering learning abroad programs have an obligation to deliver them within an appropriate framework of pedagogy and practice that can facilitate engagement between the student and the host community, provide 
opportunities for on-going reflection and exchange, and support the student through a potentially transformational learning experience.

To develop this position, this article has three objectives. The first is to present an overview of the literature on the global trend to internationalize the higher education curriculum. The second is to highlight some of the key concepts established in the work of pedagogical trailblazers John Dewey, Paulo Freire, and Jack Mezirow and synthesize them in relation to learning abroad. Finally, the article concludes with a discussion of how a synthesis of these pedagogical models, applied to the context of international learning experiences, has the potential to support transformative learning that makes a difference in how students think about and engage with complex global issues.

\section{TRANSFORMATIONAL LEARNING AND THE INTERNATIONALIZATION OF HIGHER EDUCATION}

While a comprehensive review of the vast literature on the internationalization of higher education is beyond the scope of this paper, this section offers a relevant snapshot of current trends in this area. Sources were identified by searching multiple interdisciplinary databases for publications on: higher education and internationalization of the curriculum; university programming intended to be experiential; and service oriented or practical, higher education programs that take place outside a student's normal cultural, linguistic or socio-economic setting. Preference was given to materials published in the last two decades.

UNESCO defines the internationalization of higher education as "the variety of policies and programs that universities and governments implement to respond to globalization. These typically include sending students to study abroad, setting up a branch campus overseas, or engaging in some type of inter-institutional partnership" (Altbach, Reisberg, \& Rumbley, 2009). In Canada, the Minister of International Trade's Advisory Panel on Canada's International Education Strategy recently released an in-depth report identifying international education as a "key driver of Canada's future prosperity" (DFAIT, 2012). Scholars in Australasia note that, in addition to developing cultural competence and global awareness, students see international education as a means to improving opportunities for career advancement, personal growth, and development (Chapman \& Pyvis 2006, p. 236; Welch 2012b, p. 300).

Unfortunately, as institutions around the world are rushing to internationalize and are encouraging their students to learn abroad as a part of a comprehensive education for our rapidly changing, culturally integrated society, (Alred, Byram, \& Fleming, 2006; Altbach et al., 2009; Bhandari, 2005; Brewer \& Cunningham, 2009; Gürüz, 2008) there is strong evidence that program design is often inadequate. Challenges are numerous and include uncertain learning goals, deficient pedagogy and planning, and competitive protectionism (Arcaro \& Haskell, 2009; Benham Rennick \& Desjardins, 2013b; Byram, 2006; Hellstén \& Reid, 2008; Lewin, 2009; Salmi, 2009; Shaw, Sharma, \& Takeuchi, 2009; Stearns, 2008).

In numerous cases, either overtly or subtly, programs are still steeped in a cultural context of empire building and cultural superiority (Benham Rennick, 2012b; Caluya, Probyn, \& Vyas, 2011; Chapman \& Pyvis, 2006), and, even as global society becomes more open to diversity, national and foreign policies continue to reflect inherited cultural norms and values that are identifiable in institutional and program goals (Hervieu-Léger, 
2000; Irwin-Zarecka, 1994). Research attending to issues of equitable relations, solidarity, social and pedagogical responsibilities for learning abroad has highlighted deficiencies in program planning and pedagogical frameworks (Caluya et al., 2011; Joseph, 2008, 2012; Joseph, Winzer, \& Pollard, 2006; Larsson, Boud, Abrandt Dahlgren, Walters, \& Sork, 2005; Miliszewska \& Sztendur, 2012; Ryan, 2012; Welch, 2012a, 2012b; Xiaoping, 2010). For example, Ryan (2012) notes that, despite the growing internationalization agenda, Western universities continue to rely on outdated and unquestioned assumptions about the superiority of Western academic ways. Both Ryan and Xiaoping (2010) call for genuine intercultural dialogue so that international education becomes an enterprise of mutual learning, rather than being based only on the legitimization of Western knowledge. Larsson et al. (2005), in their cross-cultural analysis of higher education in Canada, Sweden, Australia and South Africa, note that it is much easier for Western universities to simply export their programs to different parts of the world rather than engaging in a genuine collaboration with the nations and cultures in which their programs are running.

When viewed from postcolonial, feminist and minority perspectives, many of these projects are recognizable as patronizing and oppressive. These shortcomings limit students' potential to understand and uphold principles of respect and fairness and have the potential to do much harm in the arena of learning abroad where students may see themselves as culturally superior or arrive unprepared to engage with the cultural norms of their host society. That is why ideas about equitable cultural interactions require contextualized ongoing reflection and debate both in the classroom and in broader society (Benham Rennick, 2012a, 2012b, 2013a, 2013b; Benham Rennick \& Desjardins, 2013a, 2013b; Benham Rennick \& DiFruscio, 2013).

Without an intentional and focused re-examination of pedagogical priorities it will be difficult for educators to help young people prepare for, participate in, and draw meaning from their international learning experiences in a socially constructive and ethical way. Through a synthesis of the theoretical frameworks established by Freire, Dewey, and Mezirow, this is the challenge to which we now turn.

\section{LEARNING THAT MAKES A DIFFERENCE: JOHN DEWEY, PAOLO FREIRE, AND JACK MEZIROW}

As with the previous section, the literature comprised of contributions from educational innovators John Dewey (1859-1952), Paolo Freire (1921-1997), and Jack Mezirow (1927-), and subsequent efforts to interpret, reapply and analyze their philosophies, is extensive. All three scholars seek educational frameworks that can change the mind of the learner and, as a result, make a positive difference in the society in which the learner lives. Their ideas have had a profound influence on discussions about transformative learning and education for social change (Cranton, 1994, p. 48; Jarvis, 1987, p. 87; Westbrook, 1993, p. 277). ${ }^{1}$ Dewey was particularly interested in the relationship between education and participatory democracy, ${ }^{2}$ and he emphasized the importance of the link between personal experience and learning (Dewey, 1897/1969, 1903/1978). Freire (1970/2005) understood education to be a political act with the capacity to emancipate people from oppression and transform society. Following Freire, Mezirow (1991, 1997, 2000) has continued to develop a theory of emancipatory education that leads to personal transformation. A complete dissection of this literature is neither necessary nor warranted in this analysis. Instead, this section highlights several of the key pedagogical concepts in 
Dewey, Freire, and Mezirow that can be synthesized to produce a meaningful framework for individual and social transformation through learning abroad. Although referential treatment of their numerous publications is made throughout, this paper deals primarily with three texts summarizing the respective scholar's philosophy of education. These include Dewey's (1897) My Pedagogic Creed, Freire's (1970/2005) Pedagogy of the Oppressed and a chapter by Mezirow (2012), "Learning to Think Like an Adult: Core Concepts of Transformation Theory."

\section{Dewey 1859-1952: A practical framework for personal and social transformation}

Dewey comprehends an inescapable link between institutions for education and the societies in which those institutions are based. He was a proponent of a learning environment based in personal experience, involving direct engagement with the social context, including opportunities for reflection. The practical end to this process is that students should be educated and socialized to contribute to the common good. Dewey's (1897) manifesto, My Pedagogic Creed, although directed at the primary school setting, is an excellent starting point for examining his particular ideas about the purpose and place of education and social transformation.

Dewey understands education to be transformative and transformational, subjective and powerfully influential on the social context. Although Dewey's focus was not on higher education or adult learning, there is much in his work that is relevant to that context and particularly significant in the context of learning abroad and transformative education. The Creed provides several key ideas that are helpful for thinking about the kind of learning environment necessary to prepare students to effectively engage abroad. Furthermore, Dewey's perspective is suggestive of the possibilities open to students, educators, and global partners who participate in the learning abroad experience. ${ }^{3}$

Perhaps, in the context of our discussion at least, the most important idea Dewey raises in Article One of his Creed is the idea that students must find a relevant correlation between their education and their social context. He writes,

I believe that the only true education comes through the stimulation of the child's powers by the demands of the social situations in which he finds himself. Through these demands he is stimulated to act as a member of a unity, to emerge from his original narrowness of action and feeling and to conceive of himself from the standpoint of the welfare of the group to which he belongs. ${ }^{4}$ (Article One, p. 77)

The student achieves agency as a relevant member of the broader group by a process of guided, interpretive meaning making based on her own interests and experiences. The child is not solely an object waiting to be transformed in the learning process, but a subject engaged in learning that can facilitate her greater interaction within her milieu. Dewey implies that reflexivity, critical reflection, and discourse link the learning process to the social context.

This theme is continued in Article Two through Dewey's description of the school as "a social institution" and education as "a social process" (p. 78). In Article Three, Dewey identifies the subject matter of education as that which mimics the activities of "civilization" and can therefore raise a student's awareness of her social inheritance by engaging 
in "those fundamental types of activity which makes civilization what it is" (p. 78). While Dewey writes in the context of practical, everyday activities such as manual training and cooking, the idea can be applied more broadly to notions about fair play, appropriate social interactions, and empathy for the experience of the Other. This interpretation is supported in Dewey's subsequent statement that "education must be conceived as a continuing reconstruction of experience; that the process and the goal of education are one and the same thing" (p. 78).

With respect to how students should be educated, Dewey favours an approach that is first of all, "hands-on" (engaged), and secondly reflective (open to discussion and analysis). Article four of his Creed offers four sub-themes on the methods of socially transformative and relevant engaged learning. First, he explains that active learning, or engagement with the subject matter, must precede passive and symbolic learning.

When actions and symbols are integrated, the student is able to develop a personal understanding or "image" of a subject. Dewey warns that this stage requires careful attention from educators if students are to develop socially appropriate, culturally contextual, "proper images" of a subject. As the student grows in awareness, develops a symbolic lexicon, and engages more deeply with the issues, she will develop particular interests that should be encouraged rather than repressed or simply tolerated (p. 79).

The last article in Dewey's Creed establishes education as "the fundamental method of social progress and reform" (Article Five, p. 80). With the educator in the role of a "social servant" tasked with maintaining "proper social order and the securing of the right social growth" through her facilitation of the learning environment, education moves beyond simply filling heads with data. Instead, it becomes a means of forming and informing the social consciousness and inspiring action that "is the only sure method of social reconstruction." Dewey ends his Creed by summarizing the significance of the link between education and social reformation thus:

It is duly individual because it recognizes the formation of a certain character as the only genuine basis of right living. It is socialistic because it recognizes that this right character is not to be formed by merely individual precept, example, or exhortation, but rather by the influence of a certain form of institutional or community life upon the individual, and that the social organism through the school, as its organ, may determine ethical results.... (Article Five, p. 80)

Elsewhere in his extensive publications, Dewey promotes reflection as the source of goaloriented action. He explains that reflective thinking embeds meaning in events and objects so long as the student is open to the process of learning. In this, Dewey (1934/1981) identifies personal attitudes as a core aspect of social change. Done well, education has the potential to transform not just individuals but the entire social context.

\section{Freire 1921-1997: Education, politics, and freedom}

Paulo Freire, the Brazilian philosopher best known for Pedagogy of the Oppressed (1970/2005), has profoundly influenced the field of education and critical pedagogy. Like Dewey, Freire believes that the educational experience can be alienating or empowering depending on the philosophical model on which it is based. He rejects what he describes as the commonly employed "banking" approach to education wherein "deposits" 
and "withdrawals" of information occur between student and teacher (pp. 71-86). This passive exchange takes no account of the students' experience or agency and creates a power imbalance between teacher, as the knowledgeable authority figure, and student, as the vacuous beneficiary (p. 70).

Instead, Freire calls on students, in collaboration with educators, to reclaim their autonomy in the process of conscientização or "conscientization" - a concept that refers to "learning to perceive social, political and economic contradictions and to take action against the oppressive elements of reality" (p. 35, p. 74). This consciousness-raising is the source of a liberating education because it makes it "possible for people to enter the historical process as responsible Subjects" rather than mute objects to be acted upon and controlled by dominant social forces (p. 36). He describes this approach as a radical form of education:

$[T]$ he more radical the person is, the more fully he or she enters into reality so that, knowing it better, he or she can better transform it. This individual is not afraid to confront, to listen, to see the world unveiled. This person is not afraid to meet the people or to enter into dialogue with them. This person does not consider himself or herself the proprietor of history or of all people, or the liberator of the oppressed; but he or she does commit himself or herself, within history, to fight at their side. (p. 39)

By entering into discussion with others, education becomes a process of "problem posing" and "dialogue." This dialogue is rooted in words that are based in "reflection and action." Freire writes that dialogue (words and reflection on their meanings) and action are tightly bound together "in such radical interaction that if one is sacrificed - even in part - the other immediately suffers. There is no true word that is not at the same time a praxis" (p. 87). The dialogical process, therefore, is a liberating experience of engagement, reflection, solidarity and transformation both of the self, by raising one's understanding, and of society by interacting deeply and with openness to others. Freire writes, "No pedagogy which is truly liberating can remain distant from the oppressed by treating them as unfortunates and by presenting for their emulation models from among the oppressors. The oppressed must be their own example in the struggle for their redemption" (p. 54). The process of education then becomes a political act that simultaneously liberates and transforms.

Like Dewey, Freire understands education to be made relevant through its contextualization in the lived reality of the learner. Dewey's writings developed in relation to the social milieu of late $19^{\text {th }}$ century, middle-class America, whereas Freire's were based in the context of poverty and political oppression in mid- $20^{\text {th }}$ century Brazil. As such, they differ sharply in their understanding of the potential roles of educator, learner and institution. Dewey perceives educators in the benevolent position of attentive and thoughtful leadership whereas Freire aligns state sponsored education with dehumanization.

Dewey's social context allows him to posit education as a social resource that can inform one's moral framework and uphold the status quo, whereas Freire writes from a social context wherein the need for "humanization" of both the oppressor and the oppressed must precede any notion of the common good (pp.43-56). Thus Freire conceives of subjectively contextualized "educational projects" (rather than "systemic education" 
controlled by political powers) carried out in solidarity with the oppressed, as an essential resource for transformation. He writes that

The pedagogy of the oppressed, [is] animated by authentic, humanist (not humanitarian) generosity, [and] presents itself as a pedagogy of humankind. Pedagogy which begins with the egoistic interests of the oppressors (an egoism cloaked in the false generosity of paternalism) and makes of the oppressed the objects of its humanitarianism, itself maintains and embodies oppression. It is an instrument of dehumanization. (pp. 54-55)

For Freire, education that makes a difference to students and society must be based in authentic and humble human interactions. In Dewey's model, education is viewed as an institutional milieu that can facilitate social goals by encouraging a particular type of pedagogical formation based in the learner's experience and embedded in a shared conceptualization of the common good. Freire, writing from a completely different social context, identifies institutionalized education as an extension of oppressive tendencies in the state that must be subverted before a true "common good" can be established (pp. 57-59). He argues that

The only effective instrument is a humanizing pedagogy in which the revolutionary leadership establishes a permanent relationship of dialogue with the oppressed. In a humanizing pedagogy the method ceases to be an instrument by which the teachers (in this instance, the revolutionary leadership) can manipulate the students (in this instance, the oppressed), because it expresses the consciousness of the students themselves.... (pp. 68-69).

This transformation is complete when the oppressor and oppressed can develop a "cointentional education" wherein "Teachers and students (leadership and people), co-intent on reality, are both Subjects, not only in the task of unveiling that reality, and thereby coming to know it critically, but in the task of re-creating that knowledge" (p. 69). Thus, for Freire, education is not a means for sustaining the common good or upholding the status quo, instead it is the context through which ideas about what the common good should be are developed and shared. As with Dewey, the centrality of human agency and recognition are foundational in Freire's pedagogy. The differences lie in the particular social and political frameworks from within which each author writes. Taken together, these models provide a nuanced background for informing pedagogy and praxis relevant to the diversity and complexity of $21^{\text {st }}$ century global society. The work of Jack Mezirow adds a third important dimension to this discussion.

\section{Mezirow 1927-2014: Transformative learning and emancipation}

Jack Mezirow was an American sociologist and Emeritus Professor of Adult and Continuing Education at Columbia University. He is perhaps best known for his concept of "transformational learning"5 $(1981,1991,1997)$ that extends the ideas of Freire's critical theory by attending to the emancipatory potential of education that comes through critical reflection (Mezirow, 1990). ${ }^{6}$ Like both Dewey and Freire, he understands that learning is embedded in subjective experience and contextual knowledge. Mezirow's concepts of "habits of mind" and "points of view" that inform a person's "frame of reference" 
(Mezirow, 1997, p. 5; 2012, p. 82) might be viewed as an extension of Dewey's (1897) description of "images" and "proper images" (p. 77).

Mezirow (2012) defines a "frame of reference" as those "systems of belief that unite the particular with the universal" to become "worldviews" (p. 83). Frames of reference are composed of "habits of mind" and "points of view" based in "cultural, social, educational, economic, political, or psychological" experiences and expressed through "the constellation of belief, value judgment, attitude, and feeling that shapes a particular interpretation" (1997, p. 6). Changing one's habit of mind involves a "perspective transformation" akin to Freire's concept of conscientization. This can happen through discourse that encourages critical reflection that leads to the liberating process of becoming critically aware. He writes:

That is why it is so important that adult learning emphasize contextual understanding, critical reflection on assumptions, and validation of meaning by assessing reasons. The justification for much of what we know and believe, our values and our feelings, depends on the context - biographical, historical, cultural - in which they are embedded... In the absence of fixed truths and confronted with often rapid change in circumstances, we cannot fully trust what we know or believe. Interpretations and opinions that may have worked for us as children often do not as adults. (2012, pp. 73-74)

Mezirow's thinking about pedagogy becomes an important bridge between the ideas of Dewey and Friere discussed here. Mezirow dwells on the contextually embedded aspect of assumptions and interpretations of meanings and the challenge of disembedding those experiences in order to critically analyse them and recreate them more meaningfully. Like Dewey, he acknowledges the emotional aspect of learning:

Transformative learning, especially when it involves subjective reframing, is often an intensely threatening emotional experience in which we have to become aware of both the assumptions undergirding our ideas and those supporting our emotional response to the need to change. As language and culturally specific social practices are implicated in learning, understanding will be enabled and constrained by the historical knowledge power networks in which it is embedded. The assumptions of these historical networks and their supporting ideologies need to be brought into awareness and critical reflection by the learner to make possible a greater degree of autonomous learning. (2012, pp. 75-76)

The attention directed at "subjective reframing" is particularly poignant in the context of establishing pedagogy for learning abroad programs where, using the language of Freire, oppression of learning partners abroad may occur. Mezirow explains that one's "Cultural canon, socioeconomic structures, ideologies and beliefs about ourselves, and the practices they support often conspire to foster conformity and impede development of a sense of responsible agency" (p. 77). Thus, a foreign learning environment that allows one's preconceived ideas to be substantially tested would appear to be a profitable context for transformative learning. He writes: 
Transformation theory's focus is on how we learn to negotiate and act on our own purposes, values, feelings, and meanings rather than those we have uncritically assimilated from others - they gain greater control over our lives as socially responsible, clear-thinking decision makers. ( $p .76)$

Echoing Dewey and Freire, Mezirow exposes the reflexive aspect of learning as a process that simultaneously informs and is informed by the participants. In this, he sustains the argument that education has the capacity to transform the learner and, by extension, the society in which the learner lives by noting that "Transformative learning has both individual and social dimensions and implications. It demands that we be aware of how we come to our knowledge and as aware as we can be about the values that lead us to our perspectives" (p. 77).

While Dewey depicts the educational system as benevolent resource for protecting the common good, and Freire identifies it as a means of social domination, Mezirow situates the learning environment in the complex diversity of a participatory whole:

This is why it is essential to seek out and encourage viewpoints that challenge prevailing norms of the dominant culture in matters of class, race, gender, technology, and environmental protection. Agreement based on the unchallenged norms of a culture will be obviously less informed and dependable than those based on a wider range of experience. (2012, pp. 79-80)

In this description, Mezirow situates his philosophy of learning beyond boundaries that divide people by placing it in the multifaceted framework of late modern global society where recognition, participation, and agency are widely understood (if not always preserved) as inalienable human rights. Indeed, he argues that "Full development of the human potential for transformative learning depends on values such as freedom, equality, tolerance, social justice, civic responsibility, and education. It assumes that these values are basic to our human need to constructively use the experience of others to understand, or make more dependable, the meaning of our experience" (p. 82).

Mezirow invokes Freire's ideas of conscientization and emancipatory learning when he states that "Freedom involves not just the will and insight to change but also the power to act to attain one's purpose" (p. 88). Thus, a final step in the transformative process is a willingness by the learner to act on his or her new understanding by moving beyond the restrictions of the prior worldview and developing the characteristics of awareness, empathy, self control, and emotional maturity (p. 79, 88).

\section{PEDAGOGY AND PRACTICE FOR LEARNING ABROAD: A MIDDLE GROUND FOR INTERNATIONAL DEVELOPMENT?}

Several themes have been highlighted in relation to transformational learning that can make a difference to students and the societies in which they operate by helping learners to critically engage, reflect on, and act in response to complex global issues. In particular, emphasis has been given to the concepts of culturally embedded and experience-based learning followed by opportunities for reflexivity, critical reflection, and engagement that can lead to a greater sense of agency and transformative action. Comparisons between 
Dewey, Freire, and Mezirow show where these ideas overlap and diverge and situate them within the particular socio-cultural context from which they developed.

Given their shared premise that an inextricable link exists between education and society, a synthesis of key ideas developed by Dewey, Freire, and Mezirow (that have been sustained and developed further by many others) suggests a good starting point for thinking about learning abroad as a means to preparing students to engage the complexities of global society. A synthetic approach gives preference to co-intentional learning between the student and partners abroad, opportunities for on-going reflection and engagement, and a supportive context for a potentially transformational learning experience. This framework would facilitate the development of students' critical understanding and situate it in broader society through their own critically informed action plans for dealing with particular concerns and, more generally, for shaping and upholding values through which they will live their lives. This is an opportunity for learning that can make a difference to students' frames of reference and the social contexts in which they live.

Education for Dewey, Freire, and Mezirow is a deeply embedded social institution (see Figure 1) - regardless of whether it develops through subconscious cultural inheritance or in state sanctioned institutions. Of the three, Dewey places greatest emphasis on progressive interaction between individual self-development and the common good. Freire is most concerned with education that raises awareness (conscientization) and challenges an oppressive framework. Mezirow is particularly interested in the emancipatory potential of education that transforms the learner and develops a sense of agency beyond the classroom. Dewey, Freire, and Mezirow all presuppose a constructionist view of society (Dewey 1897, Article One; Freire, 1970/2005 pp. 50-51; Mezirow, 2012, pp. 76-77). They understand that human beings are simultaneously creators of their world even as the world acts back on them to inform their experiences and shape their understanding (Berger, 1967; Berger \& Luckman, 1966). They are attuned to the socio-cultural positioning of knowledge acquisition and its embeddedness in human experience within family life and culture. They share an understanding that learning should be united with

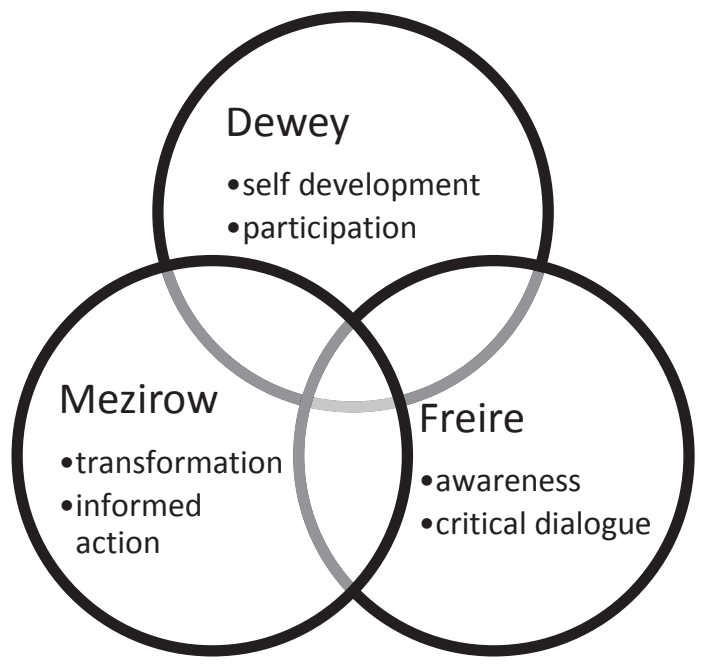

Figure 1: Critical themes in Dewey, Mezirow, and Freire 
authentic, relevant experience and have a practical goal for effecting positive change in individuals and society by 1 ) prioritizing the common good (Dewey), 2) critiquing and informing ideas about the common good (Freire), and 3) empowering individuals to act for the common good by developing better understanding of their own and other's rights and experiences within it (Mezirow). All of these writers see in education both an opportunity and a responsibility.

In the field of learning abroad, there is an opportunity for a supported learning experience allowing students to participate and collaborate in experience outside their everyday environment, discuss and reflect critically on those, and eventually, develop an action framework for responding mindfully to their experience. In this process, learnerswhether students, professors, or partners abroad-can co-create the social fabric of our world by "developing capacities of critical reflection on taken-for-granted assumptions that support contested points of view and participation in discourse that reduces fractional threats to rights and pluralism, conflict, and the use of power, and foster autonomy, selfdevelopment, and self-governance - the values that rights and freedoms presumably are designed to protect" (Mezirow, 2012, p. 91). The potential effects of such an experience have ramifications for every area of our world from how we deal with our environment to how we think about poverty.

The responsibility lies with the institutions offering these programs to establish an environment of "revolutionary" learning that allows all parties involved to engage in dialogue that can help them to comprehend "the various levels of perception of themselves and of the world in which and with which they exist" (Freire, 1970/2005, p. 95). As such, educators and students must be willing to consider not just the advantages to themselves for participating in such programs, but also the potential for harm to others. Thus students should be helped to examine and critique their positionality in the learning experience both at home and abroad so that they might truly arrive in the foreign learning environment as co-learners rather than oppressors. To do otherwise is to participate in what Freire describes as "cultural invasion" that occurs when:
Invaders penetrate the cultural context of another group, in disrespect of the latter's potentialities; they impose their own view of the world upon those they invade and inhibit the creativity of the invaded by curbing their expression. Whether urbane or harsh, cultural invasion is thus always an act of violence against the persons of the invaded culture, who lose their originality or face the threat of losing it. In cultural invasion (as in all the modalities of antidialogical action) the invaders are the authors of, and ac- tors in, the process; those they invade are the objects. (Freire,1970/2005, p. 152)

By becoming aware of our positioning within the educative process as both objects and subjects we can be made mindful of that positioning in relation to others. Dewey's broad philosophical conception of participatory democracy identifies the interconnectedness of all human beings as a fundamental aspect of human society. He writes:

In conception, at least, democracy approaches most nearly the ideal of all social organization; that in which the individual and society are organic to each other... In every other form of government there are individuals who 


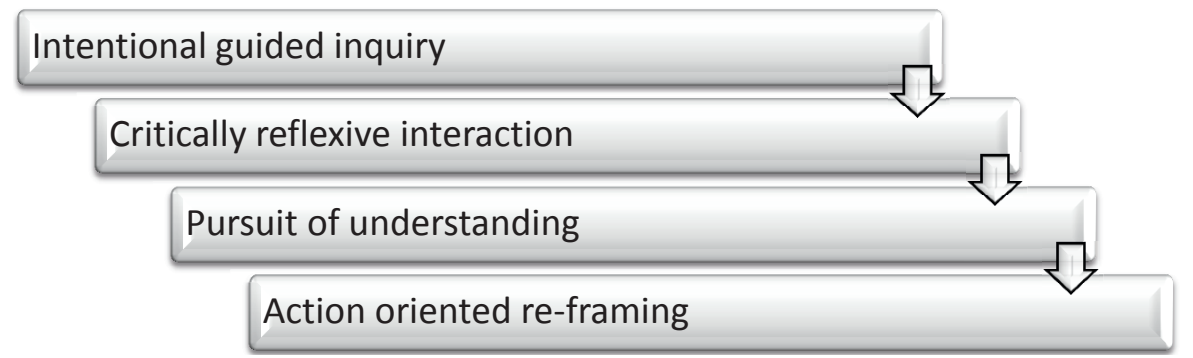

Figure 2: A synthetic approach to internationalization

are not organs of the common will, who are outside of the political society in which they live, and are, in effect, aliens to that which should be their own commonwealth. Not participating in the formation or expression of the common will, they do not embody it in themselves. Having no share in society, society has none in them. (Dewey, 1897/1969, pp. 237-238)

Thus we see in all three authors a fundamental concern that learning occur as a collaborative exercise that benefits not only a privileged learner but also protects and upholds the rights of those who work in concert with students both at home and away.

The opportunity and responsibility of education becomes particularly poignant when learning abroad experiences involve students arriving in the foreign environment as privileged outsiders. If they arrive at their internship, language learning center, homestay, or volunteer or paid employment as relatively wealthy, educated, non-natives, who may not speak the language or have prior experience with the cultural norms or conditions of the place, there is much potential for paternalism and "cultural invasion." Thus, there is also an indisputable responsibility on the part of the sending organizations, educators and participants to take steps to avoid generating learning experiences that benefit one partner while oppressing and subjugating the other.

At the most basic level, drawing on the core ideas identified in Dewey, Freire, and Mezirow, all learning abroad programs should incorporate the following four points of praxis for learning abroad. Ideally each program should be further nuanced and particularized to accommodate the learners, the type of experience abroad, and the community partners with whom students will co-learn. These points offer a starting place for thinking about further fine-tuning that will ultimately benefit all parties.

\section{Intentional, guided inquiry}

Educators should facilitate student preparation for learning abroad by exposing them to learning materials and social contexts that are personally and culturally relevant to them and their goals for going abroad. This first step serves as a means to identify and critically assess their own frames of reference, values, and assumptions before interacting with learning partners elsewhere. This step might entail reading about the future learning environment, meeting with individuals from that part of the world, or engaging in activities similar to those they will experience abroad. Alternatively, participating in activities that will simulate the social dislocation and disorientation students might experience in the international setting or foreign language environment may stimulate critical self-reflection. 


\section{Critically reflexive interaction}

Students should engage in the discursive process of challenging, reassessing, critiquing, adapting and expanding their newly identified habits of mind with a view to understanding how they might help or hinder learning in the international setting and also how these might impact partners abroad as a culturally invasive or oppressive point of view; this process should be facilitated by an educator prepared to attend to students' intellectual and emotional responses to their experiences and willing to help students explore alternative responses for understanding their learning journey. Students should be helped to pursue an attitude of humility and unpretentiousness as they enter the host environment.

\section{Pursuit of understanding}

Building on the thoughtful openness developed in stage two, once in the foreign learning environment, students should have opportunities to continue the process of critical reflection and discourse with their collaborators abroad. This may include obtaining new knowledge, having new experiences that confirm or overturn previously held assumptions, and engaging in exchanges that permit a critical reassessment of one's psycho-emotional responses to those experiences. Even in the absence of local collaborators, students can continue the process through journal writing and correspondence with other learners.

\section{Action oriented re-framing}

Finally, students should be supported on their return through a continuation of the critically reflective and discursive process and helped to develop new frames of references that can be sustained in their everyday lives. In this stage, they should be encouraged to track the development of their own awareness, identify new competencies, acknowledge cognitive or emotional challenges resulting from the experience abroad, and begin to identify competencies that might facilitate active responses to the new perspectives developed in the learning process.

As a progressive sequence that seeks to be empowering and non-oppressive, the entire learning experience must be undertaken in a context of solidarity between the educator, the student, and partners abroad. Students must be helped to move beyond egoism and humanitarianism, partners abroad should be empowered to act as co-educators and colearners rather than objects to be used for a privileged foreigner's learning experience, and educators must be willing to lead without dominating. In this model, the learning experience becomes a culturally-relevant, socially-situated, collaborative process of empowerment.

\section{CONCLUSION}

Globalization, transnationalism, and internationalization have become hallmarks of the $21^{\text {st }}$ century. Recent regional and global events such as the youth riots in the United Kingdom, civil unrest across the Arab world, the Occupy incidents, and other events are prominent examples of the various social, economic, and political challenges we now face. They are also powerful reminders of why we need to ensure our young people have meaningful, well-informed opportunities to engage critically with global perspectives. The insights students develop in learning abroad programs have implications for global 
interests by helping them to engage some of the most complex problems facing $21^{\text {st }}$ century societies.

The first part of this article examines the growing body of research on the internationalization of higher education. Much of that research points to concerns about exploitative and unfair approaches to international education. My own experiences as the former director of a learning abroad program at a Canadian university corroborate current research on this issue. Frequently, students arrive in what I refer to as "savior" or "bleeding heart" mode ready to join the struggle against suffering and inequality in the world. They are simultaneously angry at the complex problems they have inherited from previous generations, and they frequently see themselves as powerless victims in a world controlled by others. These attitudes seem to proceed from an egoism that reflects the predominantly individualistic characteristics of many developed Western societies (Benham Rennick \& Di Fruscio, 2013; Benham Rennick \& Desjardins, 2013b).

Often however, their concern for one issue can limit their ability to engage critically with other equally disconcerting problems. As the learning journey progresses, students very frequently describe themselves as discouraged, uncertain, and confused in the face of astounding complexity and seemingly insurmountable difficulties for social transformation. By encouraging students to reposition themselves in relation to the perceived problems, students must be helped to move beyond the savior/victim state of mind to a context where they can engage with others through small acts of solidarity, openness, listening and acceptance. As they make connections and gain confidence, they are frequently emboldened to act. Ongoing research by Rebecca Tiessen (2012), Tiessen and Heron (2012), and Che, Spearman, and Manizade (2009) among others, indicates this is true for students in other learning abroad programs too.

This article has proposed a synthesis of key concepts found in Dewey, Freire, and Mezirow in the context of learning abroad programs and as a means to encouraging transformative learning experiences that are both individually and socially transformational. This may be a critical moment for rethinking and reconstructing higher education for a global context, and this framework for learning abroad has the potential to create a context for "action-oriented, collaborative, real-world problem-solving education [that] can function as the most powerful means to raise the level of instrumental intelligence in individuals, groups, communities, societies, and humanity" (Benson, Harkavy, \& Puckett, 2007 , p. 25). By thoughtfully framing the learning experiences that students have, we can inspire the kind of critical, morally sound, culturally respectful, open-minded, fair, and productive education that will help humans address the challenges of our complex world. Done well, learning abroad programs at institutions of higher education around the world would not only contribute to individual and social goals but would align with international objectives to promote human flourishing.

Joanne Benham Rennick is Associate Professor of Social Entrepreneurship and Director of Social Innovation and Social Entrepreneurship at Wilfrid Laurier University.

\section{NOTES}

1. Many other scholars have helped inform and influence the concepts of transformative and emancipatory education. Jürgen Habermas, for example, was a primary influence in 
Mezirow's work. However, for the sake of brevity and the limitations of this discussion, this paper focuses primarily on Dewey, Freire, and Mezirow.

2. Dewey's perspective on democracy is applied in a broadly philosophical sense rather than a particular political context. For a further discussion of this point, see "The Ethics of Democracy" (1969).

3. The Creed stands apart from Dewey's other writings for its personal, succinct, and abrupt style. It is divided into five "articles of faith" each beginning, "I believe ...." He addresses the following topics: "Article One: What Education Is," "Article Two: What the School Is," "Article Three: The Subject Matter of Education," "Article Four: The Nature of Method," and "Article Five: The School and Social Progress." These themes describe a natural progression of practical, socially embedded learning 1 ) based in the student's subjective experience, 2) capable of informing their understanding of society, and 3) with the potential to empower the student to transform that society.

4. Dewey, like most writers in his time, uses the masculine pronoun throughout his writing. Rather than indicating this through repeated insertions of [sic], I trust the reader to understand the statements as an indicator of Dewey's social context and engage with the material through a gender neutral lens.

5. Mezirow describes the process of transformative learning thus: 1) a disorienting dilemma, 2) self-examination with feelings of fear, anger, guilt, or shame, 3) a critical assessment of assumptions, 4) recognition that one's discontent and the process of transformation are shared, 5) exploration of options for new roles, relationships, and actions, 6) planning a course of action, 7) acquiring knowledge and skills for implementing one's plans, 8) provisional trying of new roles, 9) building competence and self-confidence in new roles and relationships, 10) a reintegration into one's life on the basis of conditions dictated by one's new perspective. (2012, p. 86).

6. Mezirow has written that his own "conscientization" resulted from reading Freire and had an important influence on the trajectory of his life $(1995$, p. 8).

\section{REFERENCES}

Alred, G., Byram, M., \& Fleming, M. (Eds.). (2006). Education for intercultural citizenship: Concepts and comparisons. Bristol, UK: Multilingual Matters Ltd.

Altbach, P.G., Reisberg, L., \& Rumbley, L.E. (2009). Trends in global higher education: Tracking an academic revolution. A report prepared for the UNESCO 2009 World Conference on Higher Education. Paris, France: UNESCO.

Arcaro, T., \& Haskell, R. (Eds.). (2009). Understanding the global experience: Becoming a responsible world citizen. Upper Saddle River, NJ: Allyn \& Bacon.

Benham Rennick, J. (2012a). Canadian values and military operations in the 21st century. Armed Forces and Society, 39(3), 511-530. Epub date April 5, 2012 doi: 10.1177/0095327X12441326

Benham Rennick, J. (2012b). The new mission field? International service learning in Canadian universities. Journal of Global Citizenship and Equity Education, 2(1), 91-107.

Benham Rennick, J. (2013a). Canadian values, good global citizenship, and service learning in Canada: A socio-historical analysis. In J. Benham Rennick \& M. Desjardins (Eds.), The 
world is my classroom: International learning and Canadian higher education (pp. 28-65). Toronto, Canada: University of Toronto Press.

Benham Rennick, J. (2013b). Religion in development: Is religion a force for good? Canadian Journal of Development Studies, 34(2), 175-188.

Benham Rennick, J., \& Desjardins, M. (2013a). Towards a pedagogy of good global citizenship. In J. Benham Rennick \& M. Desjardins (Eds.), The world is my classroom: International learning and Canadian higher education (pp. 10-28). Toronto, Canada: University of Toronto Press.

Benham Rennick, J., \& Desjardins, M. (Eds.). (2013b). The world is my classroom: International learning and Canadian higher education. Toronto, Canada: University of Toronto Press.

Benham Rennick, J., \& DiFruscio, C. (2013). Culture shock, cognitive dissonance, or cognitive negotiation? Terms matter in service learning programs. In J. Benham Rennick \& M. Desjardins (Eds.), The world is my classroom: international learning and Canadian higher education (pp. 92-124). Toronto, Canada: University of Toronto Press.

Benson, L., Harkavy, I., \& Puckett, J. (2007). Dewey's dream: Universities and democracies in an age of education reform: Civic society, public schools, and democratic citizenship. Philadelphia, PA: Temple University Press.

Berger, P. (1967). The sacred canopy. Garden City, NY: Anchor Books.

Berger, P., \& Luckman, T. (1966). The social construction of reality: A treatise in the sociology of knowledge. Garden City, NY: Anchor Books.

Bhandari, A. (2005, September 28). Workers bring culture to their cubicle, Globe and Mail, p. C1.

Brewer, E., \& Cunningham, K. (2009). Integrating study abroad into the curriculum: Theory and practice across the disciplines. Sterling, VA: Stylus Publishers.

Byram, M. (Ed.). (2006). Living and studying abroad: Research and practice. Bristol, UK: Multilingual Matters Limited.

Caluya, G., Probyn, E., \& Vyas, S. (2011). Affective eduscapes: The case of Indian students within Australian international higher education. Cambridge Journal Of Education, 41(1), 85-99.

Chapman, A., \& Pyvis, D. (2006). Quality, identity and practice in offshore university programmes: Issues in the internationalization of Australian higher education. Teaching In Higher Education, 11(2), 233-245.

Che, S.M., Spearman, M., \& Manizade, A. (2009). Constructive disequilibrium: Cognitive and emotional development through dissonant experiences in less familiar destinations. In R. Lewin (Ed.), The Handbook of Practice and Research in Study Abroad (pp. 99-116). Toronto, Canada: University of Toronto Press.

Cranton, P. (1994). Understanding and promoting transformative learning: A guide for educators of adults. San Francisco, CA: Jossey-Bass.

Dewey, J. (1897). My pedagogic creed. School Journal, LIV(3), 77-80. Retrieved from http:// infed.org/mobi/john-dewey-my-pedagogical-creed/

Dewey, J. (1969). The ethics of democracy. In J. A. Boydston (Ed.), The early works of John Dewey, 1882-1888 (pp. 237-246). Carbondale, IL: Southern Illinois University Press. (Original work published 1897) 
Dewey, J. (1978). Democracy and education. In J. A. Boydston (Ed.), The middle works of John Dewey, 1899-1924 (Vol. 3, pp. 229-239). Carbondale, IL: Southern Illinois University Press. (Original work published 1903)

Dewey, J. (1981). Can education share in social reconstruction? In J. A. Boydston (Ed.), The later works of John Dewey, 1925-1953 (Vol. 9, pp. 205-209). Carbondale, IL: Southern Illinois University Press. (Original work published 1934)

DFAIT. (2012). International education: A key driver of Canada's future prosperity. Final report. Ottawa, Canada: Advisory Panel on Canada's International Education Strategy.

Freire, P. (2005). Pedagogy of the oppressed (M. Bergman Ramos, Trans.). New York, NY: Continuum. (Original work published 1970)

Gürüz, K. (2008). Higher education and international student mobility in the global knowledge economy. Albany, NY: State University of New York Press.

Hellstén, M., \& Reid, A. (Eds.). (2008). Researching international pedagogies: Sustainable practice for teaching and learning in higher education. New York, NY: Springer Publishing Company.

Hervieu-Léger, D. (2000). Religion as a chain of memory. New Brunswick, NJ: Rutgers University Press.

Irwin-Zarecka, I. (1994). Frames of remembrance: The dynamics of collective memory. New Brunswick, NJ: Transaction Publishers.

Jarvis, P. (1987). Adult learning in the social context. London, UK: Croom Helm.

Joseph, C. (2008). Difference, subjectivities and power: (de)colonizing practices in internationalizing the curriculum. Intercultural Education, 19(1), 23-39.

Joseph, C. (2012). Internationalizing the curriculum: Pedagogy for social justice. Current Sociology, 60(2), 239-257.

Joseph, C., Winzer, M.A., \& Pollard, V.A. (2006). Schooling in Australia: The interplay of education, politics, and culture. In K. Mazurek \& M. A. Winzer (Eds.), Schooling around the world. Debates, challenges, and practices (Vol. 104-119). Boston, MS: Pearson Education.

Larsson, S., Boud, D., Abrandt Dahlgren, M., Walters, S., \& Sork, T. (2005). Confronting globalisation: Learning from intercontinental collaboration. Innovations in Education \& Teaching International, 42(1), 61-71.

Lewin, R. (Ed.). (2009). The handbook of practice and research in study abroad: Higher education and the quest for global citizenship. New York, NY: Routledge Press.

Mezirow, J. (1981). A critical theory of adult learning and education [Electronic version]. Adult Education, 1, 3-24.

Mezirow, J. (1990). Fostering critical reflection in adulthood. San Francisco, CA: Jossey-Bass.

Mezirow, J. (1991). Transformative dimensions of adult learning. San Francisco, CA: Jossey-Bass.

Mezirow, J. (1997). Transformative learning: Theory to practice [Electronic version]. New Directions for Adult and Continuing Education, 74(summer), 5-12.

Mezirow, J. (2000). Learning as transformation: Critical perspectives on a theory in progress. San Francisco, CA: Jossey-Bass.

Mezirow, J. (2012). Learning to think like an adult: Core concepts of transformation theory. In E. W. Taylor \& P. Cranton (Eds.), The handbook of transformative learning: Theory, research and practice. San Francisco, CA: Jossey-Bass. 
Miliszewska, I., \& Sztendur, E.M. (2012). Australian transnational education programmes in South East Asia: Student satisfaction with the learning environment. Australian Universities' Review, 54(2), 12-21.

Ryan, J. (2012). Internationalisation of doctoral education. Australian Universities' Review, 54(1), 55-63.

Salmi, J. (2009). The challenge of establishing world-class universities. Washington, DC: World Bank Publications.

Shaw, R., Sharma, A., \& Takeuchi, Y. (Eds.). (2009). Indigenous knowledge and disaster risk reduction: From practice to policy. Hauppauge, NY: Nova Science Publishers.

Stearns, P. (2008). Educating global citizens in colleges and universities: Challenges and opportunities. New York, NY: Routledge Press.

Tiessen, R. (2012). Motivations for learning/volunteer abroad programs: Research with Canadian youth. Global Citizenship and Equity Education Journal, 2(1),1-21.

Tiessen, R. \& Heron, B. (2012). Volunteering in the developing world: Perceived impacts of Canadian youth. Development in Practice, 22(1), 44-56.

Welch, A. (2012a). Counting the cost. Financing higher education for inclusive growth in Asia. Mandaluyong City, Philippines: Asian Development Bank.

Welch, A. (2012b). Opportunistic entrepreneurialism and internationalisation of higher education: Lessons from the Antipodes?. Globalisation, Societies \& Education, 10(3), 295-315.

Westbrook, R.B. (1993). John Dewey 1859-1952. Prospects: the quarterly review of comparative education, XXIII(1/2), 277-291.

Xiaoping, J. (2010). A probe into the internationalisation of higher education in the New Zealand context. Educational Philosophy \& Theory, 42(8), 881-897. 